\title{
A Qualitative Assessment of the Health Information System in Sri Lanka Using the Health Metrics Network Assessment Tool
}

\author{
Mohamed H. Abusayeed BDS \\ Medical Officer \\ Ministry of Health \\ E-mail: mh_aboo@yahoo.com \\ Rasika G.V. Rampatige MBBS, MSc, MD, MSc \\ Consultant Community Physician \\ Ministry of Health \\ E-mail: rampatige@gmail.com \\ S.L. Peiris MBBS, MSc \\ Registrar in Community Medicine \\ Ministry of Health \\ H. Galappathi MBBS \\ Medical Officer \\ Ministry of Health \\ Sri Lanka Journal of Bio-Medical Informatics 2010;1(2):90-6 \\ DOI: 10.4038/sljbmi.v1i2.1664
}

\begin{abstract}
Informed decisions are better decisions. Unfortunately, sound information is rarely available in low-income developing countries. Health Metrics Network (HMN) is the first global health partnership that focuses on strengthening a country's health information system (HIS). Sri Lanka is one of the countries that are supported by HMN to strengthen the health information system. To do this HMN has developed a framework that provides a comprehensive approach to improving the health information system and has developed tools to assess and plan a country's health information system. Sri Lankan National Health Information System was assessed using the Health Information System (HIS) assessment tool developed by the HMN. The assessments were conducted through national and provincial level stakeholder workshops and individual expert group interviews. The assessments identified gaps in the health information system in reference to HMN gold standards particularly in areas such as data management and resource available for the health information system. However in-depth analysis is needed to identify the gaps and the causes that contribute to it to develop a good health information systems strategic plan for Sri lanka.
\end{abstract}

Keywords: Health Metrics Network; Health Information System

\section{Introduction}

Information is essential for public health actions and it is the foundation for policy making, planning, programming, and accountability. Unfortunately, sound information is rarely available in low-income developing countries. Today, countries face unprecedented demands for reliable and timely health data to support decision making, especially in the 
context of health sector reforms. Sound data are needed to ensure accountability for resources and to meet global challenges.

The Health Metrics Network (HMN) helps individual countries to improve the availability and use of accurate health information, to improve health locally and globally. HMN is the first global health partnership that focuses on health system strengthening in low and lowmiddle income countries. Health Metrics Network was designed to deliver long-lasting solutions to Health Information Systems (HIS) development ${ }^{(4)}$. Sri Lanka is one of the countries that receive HMN support to strengthen its health information system ${ }^{(6,7)}$.

HMN identifies strategies for HIS development and strengthening, supports countries in implementing HIS reforms, and increases knowledge about global public goods through research, technical innovation and sharing lessons learned to achieve this goal ${ }^{(3)}$. To do this HMN, in cooperation with a wide range of partners, has developed a framework that provides a comprehensive approach to improving health information ${ }^{(5)}$. The framework identifies assessing the current health information system as one of the important steps.

\section{Objectives}

The objectives of the assessment were

- To draw a baseline for the current HIS status - assessment findings should therefore be comparable over time;

- To inform stakeholders - for example: To inform about the aspects of the HIS, with which they are not familiar with;

- To build consensus around the priority needs for health information system strengthening; and

- To mobilize joint technical and financial support for the implementation of a national HIS strategic plan.

Current Sri Lankan Health Information System was assessed using the HMN assessment tool.

\section{Methods}

In order to assist countries in assessing the National Health Information System HMN has developed an assessment tool which describes how to undertake the baseline assessment in detail $^{(1)}$. The assessment tool covers the entire Health Information System encompassing the resources available to the system (inputs), its methods of work and products (processes and outputs) and results in terms of data availability, quality and use (outcomes). The Sri Lankan Health Information System was assessed using this tool in four steps;

- Firstly the working group identified the stakeholder group for HIS assessment as the basic principle and made them participate in assessing the national HIS. Stakeholders included the producers, users and financiers of health information and other social statistics at various national and subnational levels. 
- Secondly stakeholders from various sectors at the central level assessed the National HIS at a workshop and the findings were recorded.

- Thirdly individual interviews with key individuals/experts and groups were conducted and the findings were recorded in the HIS assessment score sheet.

- Fourthly stakeholders representing all the provinces in Sri Lanka assessed the current provincial level HIS at a workshop and the findings were recorded in the score sheet.

Subsequently all the findings were compiled and entered in the HIS assessment score sheet developed by the HMN ${ }^{(2)}$. The score sheet is a Microsoft Excel spreadsheet in which the stakeholders can enter their findings and see the results also instantly. In this assessment tool, a range of possible scenarios is provided allowing for objective and quantitative rating. The highest score (3) is given for a scenario considered Highly adequate compared to the gold standard defined by the HMN Framework. The lowest score (0) is given when the situation is regarded as Not adequate at all in terms of meeting the gold standard. In the results sheet the items with scores falling in the lowest quartile are classified as Not adequate at all. Scores falling into the next lowest quartile are classified as Present but not adequate, followed by Adequate and Highly adequate for those in the third and fourth quartiles respectively.

\section{Results}

The overall HIS assessment results are presented below. The tables 1 to 6 show the results of current status of the categories in the Health Information System in Sri Lanka. The results columns in the tables show the current status of the HIS categories in words, in colour coding (see the legends below), as percentiles and the actual points within the parenthesis.

\begin{tabular}{|c|c|}
\hline Legend & Colour Shade \\
\hline Highly adequate & \\
\hline Adequate & \\
\hline Present but not adequate & \\
\hline Not adequate at all & \\
\hline
\end{tabular}

Table 1. Situation of 'Resources for HIS' in Sri Lanka

\begin{tabular}{|l|c|}
\hline \multicolumn{1}{|c|}{ Categories } & Result \\
\hline Policy and Planning & Present but not adequate \\
& $37 \%(7.8 / 21)$ \\
\hline HIS institutions, human & Present but not adequate \\
resources and financing & $35 \%(13.5 / 39)$ \\
\hline \multirow{2}{*}{ HIS Infrastructure } & Adequate \\
\hline \multirow{2}{*}{ Overall } & $56 \%(8.3 / 15)$ \\
\hline
\end{tabular}


Table 2. Situation of 'Indicators available for HIS' in Sri Lanka

\begin{tabular}{|l|c|}
\hline \multicolumn{1}{|c|}{ Categories } & Result \\
\hline Indicators & Highly adequate \\
& $81 \%(12.1 / 15)$ \\
\hline
\end{tabular}

Table 3. Situation of 'Data Sources' in Sri Lanka

\begin{tabular}{|c|c|c|c|c|c|}
\hline Data Source & Contents & $\begin{array}{c}\text { Capacity \& } \\
\text { Practices }\end{array}$ & $\begin{array}{c}\text { Disseminati } \\
\text { on }\end{array}$ & $\begin{array}{c}\text { Integration } \\
\text { and use }\end{array}$ & Total \\
\hline Census & $\begin{array}{c}\text { Highly } \\
\text { adequate } \\
78 \%(2.4 / 3)\end{array}$ & $\begin{array}{c}\text { Highly } \\
\text { adequate } \\
89 \%(8.0 / 9)\end{array}$ & $\begin{array}{c}\text { Highly } \\
\text { adequate } \\
83 \% \\
(10.0 / 12) \\
\end{array}$ & $\begin{array}{c}\text { Highly } \\
\text { adequate } \\
89 \%(2.7 / 3)\end{array}$ & $\begin{array}{c}\text { Highly } \\
\text { adequate } \\
85 \%\end{array}$ \\
\hline Vital statistics & $\begin{array}{c}\text { Highly } \\
\text { adequate } \\
93 \%(8.3 / 9)\end{array}$ & $\begin{array}{c}\text { Adequate } \\
65 \% \\
(15.7 / 24) \\
\end{array}$ & $\begin{array}{c}\text { Adequate } \\
56 \%(1.7 / 3)\end{array}$ & $\begin{array}{c}\text { Adequate } \\
56 \%(1.7 / 3)\end{array}$ & $\begin{array}{c}\text { Adequate } \\
67 \%\end{array}$ \\
\hline $\begin{array}{l}\text { Population- } \\
\text { based surveys }\end{array}$ & $\begin{array}{c}\text { Adequate } \\
74 \%(6.7 / 9)\end{array}$ & $\begin{array}{c}\text { Highly } \\
\text { adequate } \\
81 \% \\
(9.7 / 12)\end{array}$ & $\begin{array}{c}\text { Adequate } \\
72 \%(4.3 / 6)\end{array}$ & $\begin{array}{c}\text { Present but } \\
\text { not adequate } \\
44 \%(2.7 / 6)\end{array}$ & $\begin{array}{c}\text { Adequate } \\
68 \%\end{array}$ \\
\hline $\begin{array}{l}\text { Health and } \\
\text { disease records } \\
\text { (incl. } \\
\text { surveillance) }\end{array}$ & $\begin{array}{c}\text { Adequate } \\
74 \%(6.7 / 9)\end{array}$ & $\begin{array}{c}\text { Adequate } \\
72 \% \\
(15.1 / 21)\end{array}$ & $\begin{array}{c}\text { Highly } \\
\text { adequate } \\
78 \%(2.3 / 3)\end{array}$ & $\begin{array}{c}\text { Adequate } \\
67 \%(4.0 / 6)\end{array}$ & $\begin{array}{c}\text { Adequate } \\
73 \%\end{array}$ \\
\hline $\begin{array}{l}\text { Health service } \\
\text { records }\end{array}$ & $\begin{array}{c}\text { Present but } \\
\text { not } \\
\text { adequate } \\
30 \%(1.8 / 6)\end{array}$ & $\begin{array}{c}\text { Present but } \\
\text { not } \\
\text { adequate } \\
35 \% \\
(4.3 / 12)\end{array}$ & $\begin{array}{c}\text { Adequate } \\
58 \%(3.5 \\
\text { /6) }\end{array}$ & $\begin{array}{l}\text { Adequate } \\
66 \%(6.0 / 9)\end{array}$ & $\begin{array}{c}\text { Present but not } \\
\text { adequate } \\
47 \%\end{array}$ \\
\hline $\begin{array}{l}\text { Resource } \\
\text { records }\end{array}$ & $\begin{array}{c}\text { Present but } \\
\text { not } \\
\text { adequate } \\
35 \% \\
(8.3 / 24) \\
\end{array}$ & $\begin{array}{c}\text { Present but } \\
\text { not } \\
\text { adequate } \\
34 \% \\
(11.3 / 33) \\
\end{array}$ & $\begin{array}{c}\text { Present but } \\
\text { not } \\
\text { adequate } \\
38 \%(2.3 / 6)\end{array}$ & $\begin{array}{l}\text { Present but } \\
\text { not adequate } \\
37 \%(4.4 / 12)\end{array}$ & $\begin{array}{l}\text { Present but not } \\
\text { adequate } \\
36 \%\end{array}$ \\
\hline Total & & & & & $\begin{array}{c}\text { Adequate } \\
63 \%\end{array}$ \\
\hline
\end{tabular}

Table 4 Situation regarding 'Data Management' in Sri Lanka

\begin{tabular}{|c|c|}
\hline \multicolumn{1}{|c|}{ Categories } & Result \\
\hline Data management & Not adequate at all \\
$6 \%(0.9 / 15)$ \\
\hline
\end{tabular}


Table 5. Assessment results of situation of 'Information Products' in Sri Lanka

\begin{tabular}{|c|c|}
\hline Categories & Overall \\
\hline Information Products & Adequate \\
\hline
\end{tabular}

Table 6. Situation of 'Dissemination and Use' of Health Information in Sri Lanka

\begin{tabular}{|l|c|}
\hline \multicolumn{1}{|c|}{ Categories } & Result \\
\hline Analysis and use of information & Highly adequate \\
& $81 \%(7.3 / 9)$ \\
\hline $\begin{array}{l}\text { Information use for policy and } \\
\text { advocacy }\end{array}$ & Adequate \\
\hline Information use for planning and & $50 \%(1.5 / 3)$ \\
priority setting & Adequate \\
\hline Information use for resource & $50 \%(1.5 / 3)$ \\
allocation & Adequate \\
\hline Information use for & $50 \%(3.0 / 6)$ \\
implementation and action & Adequate \\
\hline Overall & $67 \%(6.0 / 9)$ \\
\hline
\end{tabular}

The HIS assessment results are shown in the graphical format below. Figures 1 to 3 show the current status of different categories in the Health Information System in Sri Lanka. The result-bars in the graphs show the current status of the HIS categories as quartiles with the colour codes (the legends are as described above).

Figure 1. The overall HIS situation in Sri Lanka

\section{Overall HIS}

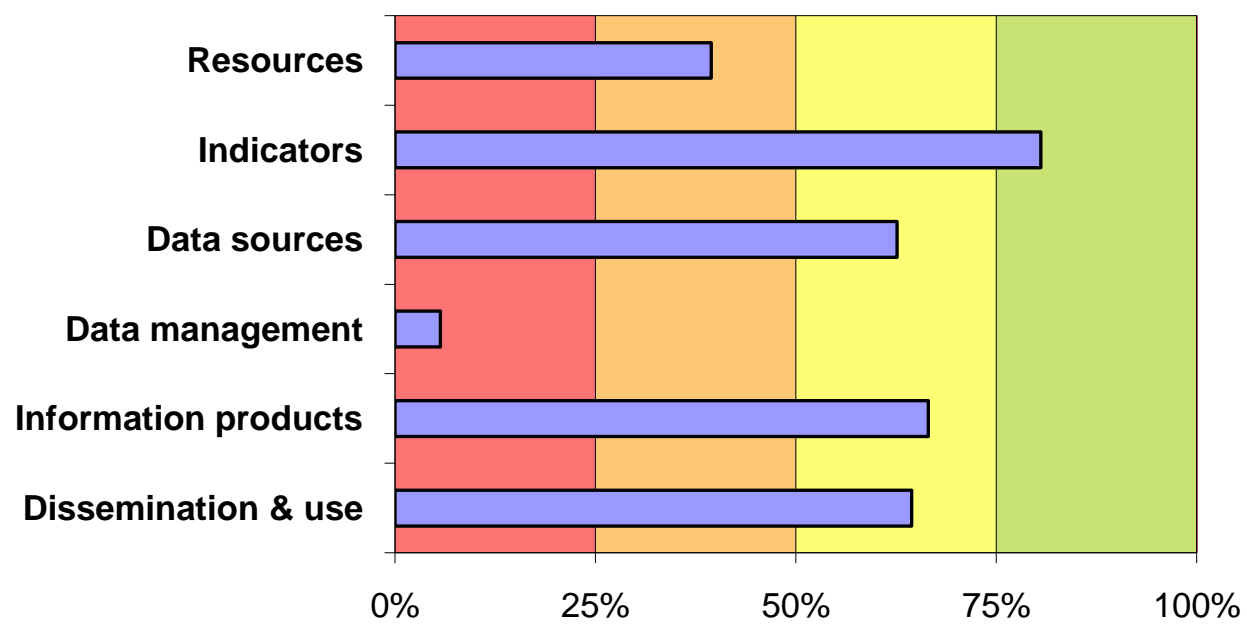


Figure 2. The situation of Resources for HIS in Sri Lanka

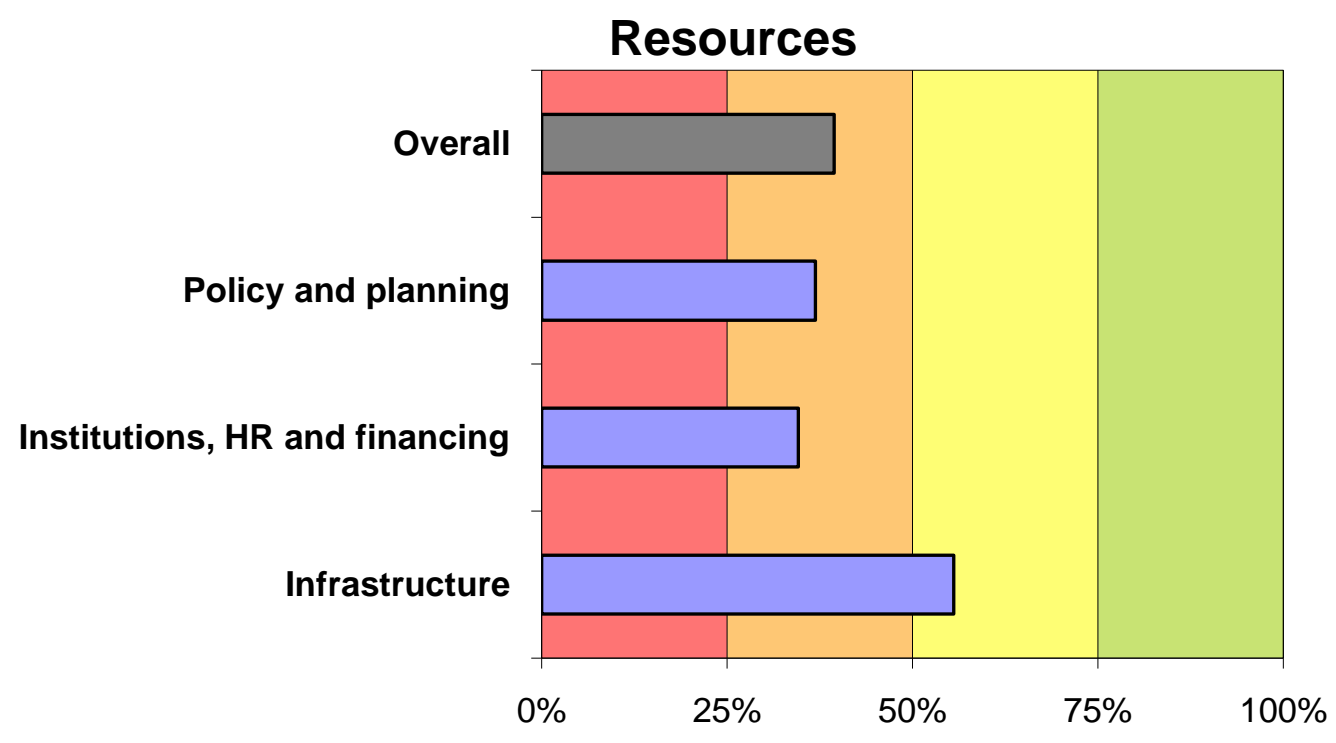

Figure 3. The situation of 'Data Sources' in Sri Lanka

\section{Data sources}

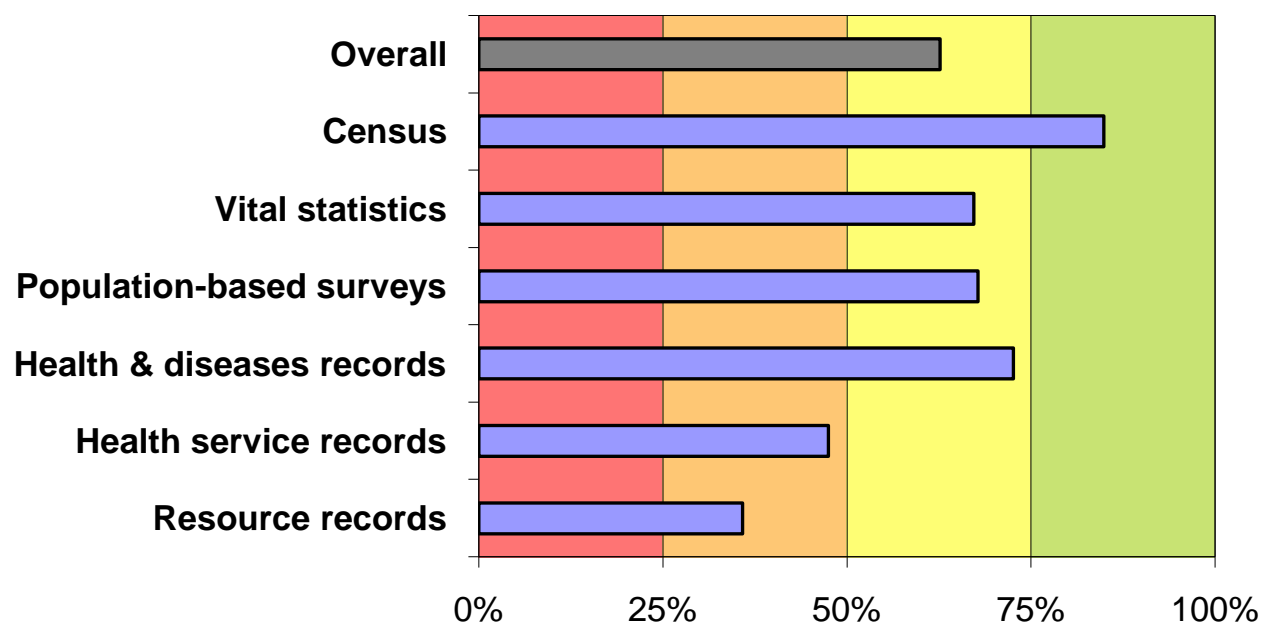

\section{Discussion}

The assessment results showed that the 'indicators' for the overall Health Information System are highly adequate while the 'data management' is not adequate at all when compare to the HMN gold standards (figure 1). The situation with regards to Data Sources, Information Products and Dissemination and Use seems to be adequate within the overall HIS whereas the Resources for HIS seem to be not adequate (Figure 1). 
The assessment shows that all the sub-components (i.e. policy and planning; institutions, human resources and financing; and infrastructure) of the 'Resources' component need to improve to meet HMN gold standards (Figure 2).

When considering the data sources (Figure 3) in the HIS, census data seems to be meeting the HMN gold standards. However other components such as vital statistics, populationbased surveys, health and disease records, health service records and resource records need to improve to meet the HMN gold standards.

\section{Conclusion}

Quality Health Information is the key to effective evidence-based management of the Health System. The results of these assessments should be used as baseline findings for future planning, monitoring and evaluation of HIS development programs in Sri Lanka. A meticulous in depth analysis should be carried out to identify gaps in the HIS and factors that contribute to creation of such gaps to plan to meet the HMN standards in the future. In conclusion the study point towards the need for immediate interventions to improve the present state of the Health Information System in Sri Lanka.

\section{References:}

1. Assessing the national health information system: an assessment tool. - Ver. 4.00, World Health Organization. Geneva, 2008. [Online]. [cited 2010 April 05]; Available from URL: http://www.who.int/healthmetrics/tools/3_HMN_Assessment_Tool_Version_4_0_Eng.pdf

2. Assessing the national health information system: Assessment Score Sheet - ver. 4.00, World Health Organization. Geneva, 2008. [Online]. [cited 2010 April 05]; Available from URL: http://www.who.int/healthmetrics/tools/3_HMN_Assessment_Tool_Version_4_0_Eng.pdf

3. Components of a strong health information system, A guide to the HMN Framework. Health Metrics Network: Geneva. [Online]. [cited 2010 April 05]; Available from URL: http://www.who.int/healthmetrics/en/

4. Framework and Standards for Country Health Information Systems. World Health Organization. $2^{\text {nd }}$ ed. Geneva: June 2008. [Online]. [cited 2010 April 05]; Available from URL: http://www.who.int/healthmetrics/documents/hmn_framework200803.pdf

5. The need for strong health information systems, Rationale for the HMN Framework. Health Metrics Network: Geneva. [Online]. [cited 2010 April 05]; Available from URL: http://www.who.int/healthmetrics/tools/theneedforstrong_his.pdf

6. Sri Lanka: Assessment Scoresheet [xls 706kb] [Online]. [cited 2010 April 05]; Available from URL: http://www.who.int/healthmetrics/library/countries/lka/en/index.html

7. HEALTH METRICS NETWORK NEWSLETTER | FEBRUARY 2008 ISSUE http://www.who.int/healthmetrics/documents/hmn_news_vol_8.pdf 